\title{
Neutralism policy and non-alignment foreign policy Challenges analysis of Sri Lanka: during the post- war period in Sri Lanka.
}

\author{
P.K.B. Isuru Premarathna \\ University of Kelaniya, Sri lanka,
}

\begin{abstract}
Foreign policy and foreign policy components are directly influencing the success of the national aspirations of the state. This research explores the independence of Sri Lanka's national and international foreign policy from foreign principles and the role of foreign policy in Sri Lanka after the end of the thirty decades of war, and from a research point of view of neutrality and non-aligned foreign policy. The main objectives of the research are to identify the challenges of Sri Lanka's foreign policy in the post war period in Sri Lanka and to study the positive and negative aspects of neutral and non-alignment policy. The data triangulation method has been used to accumulate secondary data from multiple sources available in electronic and printed form, including books, journals, the web, reports, historical records and treaties. Qualitative content analysis has been used since this is a documentary analysis and Content analysis, evaluate, document texts and to test theoretical relevance to understand data more comprehensively and scientifically. It will test prevailing theories in different contexts when compare the categories of different settings. Sri Lanka's foreign policy can be established as a neutral policy. And the neutral policy taken on a dual nature. There is a policy of neutrality in war camps and a policy of friendship and non- alignment relations with states in foreign relations. Economic relations were the driving force of foreign policy during the postwar period in Sri Lanka. According to the research, human rights, maritime security strategies and geopolitical challenges can be identified as the main positive and negative challenges of Sri Lanka's foreign policy in the post war period. And other foreign policy problems are in bilateral and multilateral foreign policy can also accountability, the peace process, anti-terrorist laws for disarmament, and the propensity for human rights.
\end{abstract}

Keywords: Neutralism policy, non-alignment, foreign policy Challenges, Sri Lanka, post war 


\section{5th International Conference on New Findings On HUMANITIES AND SOCIAL SCIENCES}

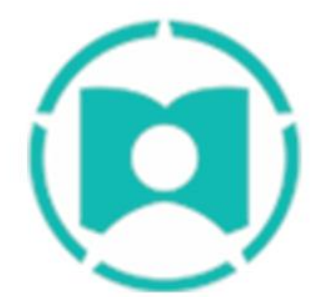

20-22 NOVEMBER, 2020 PARIS, FRANCE

\section{Introduction}

\section{Foreign policy}

A state's foreign policy is consistent with its objectives and activities in its dealings with other states, either bilaterally or through multilateral platforms. The Encyclopedia Britannica emphasizes that a country's foreign policy may be influenced by national considerations, policies or behaviors of other states, or plans to advance specific geopolitical concepts. The general objectives governing the activities and relations of a State in its interactions with other States. Foreign policy making is influenced by national considerations, policies or behavior in other countries or by specific geopolitical plans. Leopold von Ranke stressed the primacy of geography and external threats in the formulation of foreign policy, but later the authors focused on domestic factors. Diplomacy is the instrument of foreign policy, and war, alliances and international trade may prove this.

\section{Non- Aligned Movement (NAM)}

The Movement of Nonaligned Countries (MNA) is a forum of 120 developing countries that are not officially aligned with or against a large power bloc. After the United Nations, this is the largest cluster of states in the world. Drawing on the principles agreed at the Bandung Conference in 1955, the Non-Aligned Movement was established in 1961 in Belgrade, SR Serbia, Yugoslavia through an initiative of the Indian Prime Minister Jawaharlal Nehru, Ghanaian President Kwame Nkrumah, Indonesian President Sukarno, Egyptian President Gamal Abdel Nasser and Yugoslav President Josip Broz Tito. This resulted in the first Conference of Leaders of Nonaligned Countries. The term non-aligned movement appeared for the first time at the Fifth Conference of 1976, when the participating countries were designated as "members of the movement".

The purpose of the organization was enumerated by Fidel Castro in his Havana Declaration of 1979 as to ensure "the national independence, sovereignty, territorial integrity and security of non-aligned countries" in their "struggle against imperialism, colonialism, neocolonialism, racism, and all forms of foreign aggression, occupation, domination, interference or hegemony as well as against great power and bloc politics." The countries of the Nonaligned Movement represent close to two thirds of the members of the United Nations and represent $55 \%$ of the world's population. Accession is particularly concentrated in those countries considered to be developing or part of the Third World, even though the Nonaligned Movement also includes a number of developed countries.

Although many of the Non-Aligned Movement's members were actually quite closely aligned with one or another of the superpowers (such as the People's Republic of China, an observer, or the Soviet Union, not participating in the Non-Aligned Movement), the movement still maintained cohesion throughout the Cold War, even despite several conflicts between members which also threatened the movement. In the years since the end of the Cold War, it has focused 


\section{5th International Conference on New Findings On HUMANITIES AND SOCIAL SCIENCES}

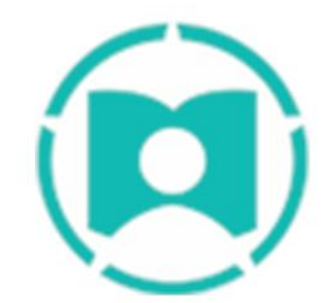

\section{0-22 NOVEMBER, 2020 PARIS, FRANCE}

on developing multilateral links and unity among the developing countries of the world, particularly those in the South.

\section{Neutralism and Nonalignment}

The terms "neutralism" and "non-alignment" were used vaguely and interchangeably in the 1960s to denote the desire of a majority of African-Asian nations to avoid military alliances with both sides during the Cold War. They are connected with the two most important international developments of the post-World War $\mathrm{n}$ era: Foremost, the issue of independent states in Asia and Africa, ending three centuries of Western European expansion; And second, the issueissueolar struggle between the United States and the Soviet Union, each in possession of weapons capable of global destruction.

The terms are unclear to the old notion of "neutrality", which referred to a legal requirement in which a country refrained from taking sides in a war between two or more belligerents. The laws of neutrality, which were formed primarily by treaties of the 17th and 18th centuries reinforced by judicial decisions in the 19th century, delineated specific rights and responsibilities for belligerents and neutrals. Neutral states, for example, have accepted not to help the belligerents or to allow their citizens to do so. Citizens of neutral states who assisted a belligerent would be deprived of protection by their own government and could be punished under the laws of their own country. In turn, the warring parties had to respect the business activities of the neutral. Attacks by combatants on neutral ships often marked the end of neutrality. However, in the absence of an international authority having the power to impose neutrality, the observation of neutral «rights» by the warring parties depended on their interests and power. The rights of the neutral were largely trampled during both World Wars, and after World War II, Hardly anyone, with the exception of Switzerland and Sweden, saw neutrality in the legal sense as a viable policy of maintaining independence.

Neutrality meant a policy followed during a belligerent state. In a specific conflict, even a big power can choose to stay neutral. Smaller and weaker powers sometimes declared themselves in a state of neutralization, that is, they chose to be in a state of perpetual neutrality in every war. Switzerland is the most frequently cited examples of deactivation, and the 1955 Austrian Peace Treaty provided for the permanent deactivation of Austria. Neutralization should be distinguished from demilitarization, which refers to the lack or limitations of a nation's ability to engage in war, while neutralization prohibits participation in a state of war. A country can be demilitarized but not neutralized (Japan in the 1950s) or neutralized, but not demilitarized (Austria after 1955).

No new nations in Asia and Africa, except Laos, have declared themselves demilitarized or neutralized. Indeed, the leaders of the new nations rejected the negative association of the term 'neutral' and its implication of indifference, isolationism and a position in world affairs that denied the full exercise of their sovereign powers. Indian Prime Minister Jawaharlal Nehru, 


\section{5th International Conference on New Findings ON HUMANITIES AND SOCIAL SCIENCES}

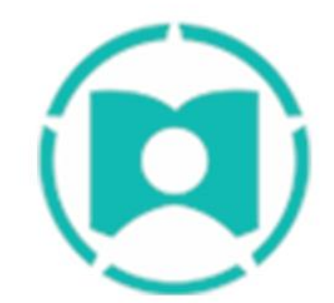

\section{0-22 NOVEMBER, 2020 PARIS, FRANCE}

one of the first spokespersons for emerging countries, preferred to refer to "non-alignment" rather than neutralization, and the President of the United Arab Republic, Gamal Abdel Nasser, used the term "positive neutrality". At a meeting in Belgrade on September 1961, sponsored by Nehru, Nasser, President Kwame Nkrumah of Ghana and President Tito of Yugoslavia, the term "non-alignment" rather than "neutralization" was generally used, and the conference has been referred to as the Conference of Nonaligned States. A proposal by Prime Minister Nehru that the traditional neutrals, Ireland and Sweden, be invited, was turned down by the other patrons, who thereby made clear the distinction in their minds between neutralism or nonalignment as a state of noncommitment in the cold war and neutrality as a legal concept.

Although the desire for greater independence VI's-à-vi's the two great powers has been expressed throughout Europe, it is among the newly independent nations that there is usually a policy of neutralization and non-alignment. The terms are ambiguous, so labeling a 'nonaligned' country says little about its motivations or how its neutralization is implemented. Countries with close ties to the French Community or the British Commonwealth, as well as countries closely associated with the Soviet Union or the People's Republic of China, can call themselves "neutralizers" or "non-aligned". The terms also cover those who are displaced for fear of Western or Communist expansion, as well as those who use it as a shield for their own expansionist policies. When we talk about neutralization, we are talking more generally about the foreign policy of emerging nations.

Non-alignment was popularised for the first time by Indian Prime Minister Nehru. Nehru made it clear that while a newly independent India would be active in the United Nations, retain her membership in the Commonwealth of Nations (as a republic), and seek to play a "positive" role in international affairs, she would not become "entangled in any alliances, military or other that might drag us into any possible conflict" (Nehru 1950). Nehru saw the fight between the United States and the Soviet Union as a rivalry for world power, not as an expression of ideological differences. It is useful to recall that the preoccupation of Americans and Western Europeans with communist expansion occurred at a time when Indian nationalists and other Asian and African nationalists were fighting colonialism or fighting against the immediate issues related to independence. As a result, the first Conference on Relations with Asia, held in New Delhi in March 1947, on the eve of India's independence, focused on colonialism and mutual cooperation in Asia.

But Nehru was very preoccupied by the possibility of a war between the great powers that would inevitably engulf the entire world. He believed that India could serve as a channel of communication among the major powers - which it did during the Korean War-and play a role of moderator, if not mediator. Within a few years after India became independent, the terms "nonalignment" and "neutralism" became more widely adopted: by countries in Asia and Africa, which had newly achieved independence, by Egypt after a revolution overthrew the traditional monarchy, and by Yugoslavia when it announced its independence from the Soviet Union. The terms were quickly used interchangeably, not as analytical concepts but as popular terms which in fact covered a wide range of policies. Nevertheless, the terminology itself is of 


\section{5th International Conference on New Findings On HUMANITIES AND SOCIAL SCIENCES}

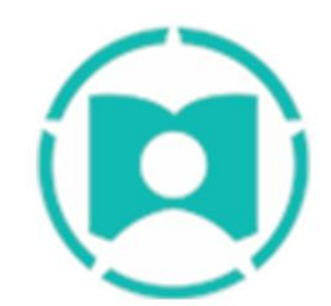

\section{0-22 NOVEMBER, 2020 PARIS, FRANCE}

political importance, as a line has been drawn in international conferences between those countries which have subscribed to it and those which have not.

Neutralism and nonalignment for the moment we shall cast aside the broad scope of policies which these terms encompass can be viewed as (1) a strategy for maximizing one's security in a bipolar world; (2) a foreign policy expression of domestic political, ethnic, and psychological needs; And (3) a policy of newly independent countries for securing their regional interests.

Sri Lanka's strategic location makes it not only a South Asia, but a state in the Indian Ocean as well. The space of the Indian Ocean presents a critical geostrategic parameter for the reflection of Sri Lanka in foreign and defence policy. The defence-strategic concerns related to its location as (i) a small island state, (ii) located in the southern tip of South Asia but separated by a narrow water column from India and (iii) strategically positioned at the center of the Indian Ocean linking its Eastern and Western flanks have conditioned Sri Lanka's approach towards the Indian Ocean. However, only geostrategic considerations do not dictate the direction of foreign policy. Formulating foreign policy involves a complex process in which "defining the situation" forms the reality and expectations upon which decisions are made. Apart from strategic factors, interests, values, attitudes and images facilitate the perception of reality1. The interpretations of the strategic factors of the localization of Sri Lanka over time that mediated the perception of reality were strongly conditioned by national political and economic constraints. As a result, Sri Lanka's focus, political priorities and approaches to the Indian Ocean have constantly fluctuated over the past 70 years. This paper aims to trace these changes from a more general historical perspective and to identify the factors and conditions that led to these changes.

Sri Lanka had been trapped for a quarter of a century in a long bloody and seemingly intractable separatist war until 2009, when the government crushed the separatist forces and secured a decisive military victory. This victory was widely praised by the majority of the Sri Lankan population and by the international community despite the discomfort about the conduct of the army during the conflict. The end of the war sparked renewed optimism about Sri Lanka's economic prospects, with widespread expectations of a peace dividend that would enable Sri Lanka to launch into a period of sustained economic growth.

Immediately following the conflict, this optimism seemed to be confirmed. The government was well entrenched with a dominant majority in the legislature and strong popular support (at least in the majority community). The opposition was profoundly divided and politically weakened. Initially the international community was reluctant to subject the Sri Lankan government to any serious political pressure over its handling of the war and reported atrocities, though the EU decided to terminate preferential access to the EU for Sri Lankan garment exports, and aid and assistance flowed in from traditional Western donors and international agencies as well as from China and India. The tourism sector, heavily affected by the war, is recovering strongly. Domestic political stability and the international community's acceptance 


\section{5th International Conference on New Findings On HUMANITIES AND SOCIAL SCIENCES}

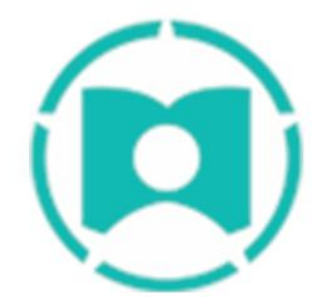

\section{0-22 NOVEMBER, 2020 PARIS, FRANCE}

of the government's legitimacy have allowed the government to raise additional funds through commercial borrowing and to implement major public spending programs. It seemed that the window of opportunity for an end to the conflict was seized by the government to steer the country towards political reconciliation and economic growth.

With renewed confidence in the country, Sri Lanka has enjoyed an important economic recovery. GDP growth in 2010 reached $8 \%$, up from $3.5 \%$ in 2009, inflation came down from $22.6 \%$ in 2008 to $6 \%$ in 2010, unemployment fell from $5.7 \%$ in 2009 to $4.9 \%$ in 2010, the fiscal deficit narrowed, foreign reserves went up, and the Colombo stock market, having nearly doubled in value in 2010, was the second best performer among global markets for two years running. Only, as the large and rapidly developing literature on post-conflict recovery has shown, though a revival of growth in the immediate aftermath of an end to a violent conflict is frequently mentioned, there is no guarantee that such a recovery would be kept over the medium to long term. 2In the case of Sri Lanka, optimism did not delay. In 2011, developments in economic policy and the political arena began to raise concerns regarding the sustainability of the recovery. In early 2012, in the context of slowing economic growth, a sharp deterioration of the current account and rapidly declining foreign reserves, the authorities were compelled to undertake a series of measures that involved a substantial devaluation of the currency, unpopular measures to curb public expenditures and increased reliance on short term commercial borrowings in international capital markets

In this paper, we examine the Sri Lankan experience, recognizing that a range of factors, including the particular historical context and the nature of social and political institutions, interact in a complex way to determine what economic and political change within countries and communities is. In particular, we consider how the nature of the political coalition that allowed the military victory has, in turn, had a major influence on post-conflict economic policies in a way that can undermine the country's long-term growth outlook. Though we do not address it explicitly in this paper, the Sri Lankan experience also has relevance for the broader debate on the role of ethnic diversity on economic development, where it has been argued that ethno-linguistic fractionalisation and associated political polarisation results in under-supply of public goods and higher levels of rent seeking activity.

\section{Objectives of the study.}

The principal aims of the research are to identify the challenges of Sri Lanka's post-war foreign policy in Sri Lanka and to study the positive and negative aspects of the policy of neutrality and non-alignment.

Other objectives of the research are to study the post-war role of Sri Lanka's foreign policy and economic and diplomatic relations in external relations, and look at the impact of foreign policy on economic growth in Sri Lanka. 


\title{
5th International Conference on New Findings On HUMANITIES AND SOCIAL SCIENCES
}

\section{(10) \\ 20-22 NOVEMBER, 2020 \\ PARIS, FRANCE}

\begin{abstract}
Methodology
This article uses an objective and interpretative methodology, an empirical epistemology and a descriptive and analytical approach. Basically, this research is a qualitative investigation. The paper approaches research questions using primary and secondary sources. In addition, the data triangulation method was used to accumulate secondary data from multiple electronic and paper sources, including books, journals, the Web, reports, historical documents and treaties. Qualitative content analysis was used as a literature review and content analysis, an evaluation of the text of the documents, and a test of theoretical relevance to gain a more complete and scientific understanding of the data.
\end{abstract}

It will test dominant theories in different contexts by comparing categories of different contexts when we evaluate this study, it has used some basic methodologies to achieve the objectives of the study. The study used qualitative secondary data from e-books, websites, books, journals and magazines, research articles and scholarly articles to gather extensive knowledge. The study used documentary analysis and conceptual analysis as fundamental analytical methods. Documentary analysis defines a pattern of qualitative inquiry in which documents are rendered by the researcher to present a meaningful subject. In the literature review, it collects available documents and data that are related to the particular study and interprets them to identify the specific issue. The conceptual analysis is often developed around a review of the study documentation associated with the design under study. This can be exemplified more as an investigative process that explores the concepts for.

\section{Finding and Discussion}

\section{The Post-War Directions}

At the end of the long-running war after a fierce military victory in 2009, Sri Lanka was at a critical historical turning point in its post-independence historical development. Ever since this war ended, Sri Lanka's geo-strategic position in the context of the evolving strategic outlines of the Indian Ocean has evolved and its foreign policy priorities have undergone significant change in the face of the new challenges facing Sri Lanka. His relations with the United StatesUnited, the European Union and Canada were on a downward track due to pressure on Sri Lanka to investigate Sri Lanka's human rights record and alleged war crimes committed in the war's phase. How to deal with resolutions sponsored by Western powers at UNHCR on alleged violations of international humanitarian law and any other action on this issue has become the main preoccupation of post-war foreign policy in Sri Lanka. Under the leadership of President Mahinda Rajapaksa, Sri Lanka drew closer to the powers that offer a shield against such movements and balance Western political and economic pressures. Within the global and Indian Ocean context, Sri Lanka's relations with China have acquired a renewed politicalstrategic significance. Seno-Sri Lanka relations in many spheres have grown rapidly and China has become the main source of foreign direct investment from Sri Lanka. Major projects with Chinese loans include the deepwater port of Humbantota and the Colombo International Financial City (Port City) to be built on reclaimed land. The political and policy aspects of 


\section{5th International Conference on New Findings ON HUMANITIES AND SOCIAL SCIENCES}

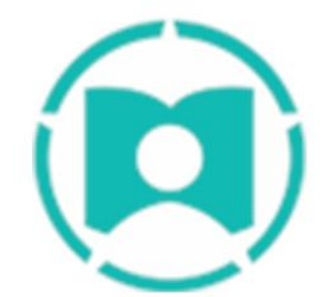

\section{0-22 NOVEMBER, 2020 PARIS, FRANCE}

these issues must be considered in the context of the concerns of other Indian Ocean powers, especially India, the United States and Japan. Sri Lanka has repeatedly asserted that Hambantota will simply be a commercial port and has categorically denied speculation that it will be part of China's so-called string of pearls strategy. The national opposition has warned that Sri Lanka is being consciously or unconsciously drawn into the new Cold War in the Indian Ocean between China and the United States.

After the government of national unity took over on January 8, 1915. The priorities of Sri Lanka were reset. The Indian Ocean has once again been a top foreign policy priority for the government. That was reflected in the establishment of the Indian Ocean Secretariat, which reported to the Prime Minister. He emphasized that the Indian Ocean region is about to define the destiny of the world in the 21 st century and that the geopolitical turn of events in the Indian Ocean has made it the Ocean of the Futur11. Three main elements of the Government of National Unity's approach to the Indian Ocean area can be identified. One was to bring the concept of balance back into the Indian Ocean approach. India is the emergent navy power of blue water on the threshold of Sri Lanka. China is the global powerhouse in the close vicinity with the expansion of the naval role in the Indian Ocean. The USA is the naval powerhouse of the Indian Ocean. China is the largest contributor to FDI. One lion's share of Sri Lanka's export market remains with the West; $27 \%$ of total exports go to the United States and another 27\% and $10 \%$ go to the EU and the United Kingdom respectively. India is Sri Lanka's number two trading partner. In this context, the maintenance of a balanced relationship with all these key powers which are the main players in Indian Ocean policy was seen as an issue of the utmost importance. As a result, the Government of National Unity believed that any form of long-term strategic alignment with any authority would not serve Sri Lanka's national interests, despite long-term financial gains. Second, the government of national unity has placed economic diplomacy first in its approach to the Indian Ocean. The government recognized that rebalancing world economic and financial power with the growth of Asian power centres would make the Indian Ocean the gravity of world economic power. In that context, how to take advantage of Sri Lanka's strategic location and other human resources to be an integral part of Asian prosperity has become a key political challenge. Third, Sri Lanka believed that a singlepower domination of the Indian Ocean, either by China, India or the United States, would put Sri Lanka's national interests at a disadvantage. In the current critical stage of strategic developments in the Indian Ocean, a small island state like Sri Lanka can only remain as an observer. The Indian Ocean region still has a long way to go to be a transoceanic community through naval ties. The freedom of navigation and security of sea-lanes of communication in the Indian Ocean constituted the basic element of it The Foreign Minister Mangala Samaraweera stated at the Galle dialogue in 2016 that "It is important to focus attention on the importance of building rules based maritime security architecture, respecting international law that can mobilize all stakeholders to create, preserve and maintain peace and stability in the Indian Ocean". The "rules-based maritime order" seems to be the defining word of the NFU government in its approach to the impending "New Cold War" in the Indian Ocean. 


\section{5th International Conference on New Findings ON HUMANITIES AND SOCIAL SCIENCES}

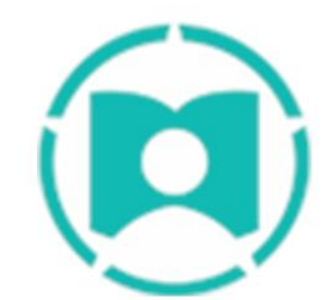

\section{0-22 NOVEMBER, 2020 PARIS, FRANCE}

Concentration on safety in a traditional realistic sense. "Complex interdependence refers to a spot among a number of nations in which multiple channels of contact connect societies (that is, states do not monopolize these contacts); there is no hierarchy of subjects; and military strength is not applied by governments toward one another" (Keohane \& Nye, 2012, pp. 265). By corroborating the existence of a complex interdependence in Sri Lanka's links to India and China, the document describes the complexity of articulating a foreign policy for the island. The next section is based on the existing scientific consensus in favour of a "balanced" foreign policy. Some academics and policy makers advocate 'friendship with any foreign policy' (De Silva, 2016; Karunanayake, 2017a; Ockersz, 2017, para. 8; Sirisena, 2016) other nstersress that the current management wishes to keep a' Asia centric middle path' (Senadhira, 2017). During his short term in office as Foreign Minister, Mr. Karunanayake (2017b) was also synonymous with trade diplomacy in bringing win-win situations to the island. Commenting on Colombo's gender relations Political scientist Uyangoda says that "Avoiding an ideological identity in its foreign policy strategies seems to be a key feature of the Maithripala Sirisena-Ranil Wikremasinghe administration right now" (2016, para. 2). In addition, Panditaratne (2017, paras. 10) states that "Sri Lanka seeks to forge a dual identity as the centre of the Indian Ocean and the economic gateway to the Indian subcontinent." These various perspectives on current foreign policy should also be placed in the context of Sri Lanka's plans to become "a pole of the Indian Ocean" (Samaraweera, 2017). What emerges from this superficial review is the observation that the present administration of President Sirisena has attempted to forge links with India and China. The next section examines the strategic competitiveness between China and India in South Asia and the potential trajectory of their bilateral relationships in the changing geopolitical environment of the 21st century. This section details the ties between India and China, highlighting the flow of their bilateral relationships as well as the reasons for the tensions between the two states.

The paper then contrasts the foreign policy of former President Rajapakse and his successor Maithripala Sirisena in terms of their ties with New Delhi and Beijing as well as the degree to which both India's and China's strategic, economic and military concerns were taken into account when formulating the foreign policy of the island. The following section explores the feasibility of a balanced foreign policy for the island and the ability of President Sirisena to pursue this course in the near future given the constraints that his administration faces. The author concludes that a balanced foreign policy has been implemented by President Sirisena but outlines four main scenarios that the island could face in the future, three of which are direct obstacles to maintaining a balanced foreign policy. Although I note that these are not the only plausible situations that Sri Lanka may face, these cases seem to be the most likely in the future. In considering these scenarios, I underline the importance of implementing a multi-actor perspective.

01. Better analyze the implications of developing linkages with both and States.

02. Explore the various implications and possible problems or causes of conflict that may occur in Sri Lanka's relations with India and China. 


\section{5th International Conference on New Findings On HUMANITIES AND SOCIAL SCIENCES}

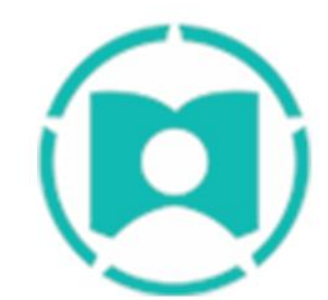

20-22 NOVEMBER, 2020
PARIS, FRANCE

Based on the complexities involved in the navigation between the two Asian giants, the paper argues that to ensure the security and economic interests of Sri Lanka, a multi-stakeholder approach should be implemented by the Sirisena administration. Passed on the present administration's desire to keep a balanced foreign policy in relation to India and China it is imperative that the foreign policy decision making apparatus combines authoritative figures in academia and other institutions to navigate the islands external relations amidst the tense geopolitical environment in Asia. A multi-actor approach focuses attention on 'the legitimacy of multiple actors in a specific setting, instead of donning an all-encompassing legitimacy for one player in all contexts' (Gjørv, 2012, pp. 13). Such a multi-stakeholder approach would make it possible to pool resources in academic institutions, human rights and reconciliation non-governmental agencies as well as other international relations institutions based in the. the Bandaranaike Center for International Studies, the Regional Center for Strategic Studies, the Sri Lankan Institute of National Security Studies, and the Institute of Policy Studies, etc. Although this multi-stakeholder approach focuses mainly on the institutions and academia of governmental and non-governmental organizations, further steps can be taken to extend this approach at the regional level if the need arises. The use of such a multi-stakeholder approach allows foreign policy makers to determine the parameters or boundaries of what is, or is not, a part of the security dynamic at a given time. It also allows us to use multidimensional insights in academic and institutional networks about the positive and negative implications and externalities of pursuing a particular course of action. This foresight allows us to better judge a decision that will benefit Canada in the short and long term. A multi-stakeholder perspective would make it possible to pool resources to analyze possible options and implications of monitoring different foreign policy options on a contextual basis. This would allow policymakers to examine a particular case from different angles and weigh the cost and benefits from a political, economic and social perspective. This is why Sri Lanka would do best if it were to embrace such a policy given President Sirisena's continued desire to operationalize a balanced foreign policy between the two rising powers - who are increasingly prone to engage in conflicts and encounters on many battlefronts in the years before.

\section{The peace diplomacy of Sri Lanka.}

Is there a peace diplomacy (multilateral and focused on a peace program) specific to Sri Lanka? There are a number of responses to that question. It can be argued that Sri Lanka enjoyed a clear peace thanks to the delegations of States in the 5th century. The epic Ramayanaya stated that Ravana (demon king of Lankadeepa now Sri Lanka) characterized his intention for a peace dialogue with Rama (seventh avatar of the Hindu god Vishnu - king of Ayodhya, India). The leaders of the former Kingdoms experienced shared peace and prosperity among traders, travellers and even with warriors outside the island. Similarly, peace diplomacy through written and unwritten sources has documented the national character of Sri Lanka in relation to peaceful diplomatic cooperation. The "new" form of diplomacy inculcated since independence in 1948, the well-known state intervention in favour of peace diplomacy was evident when J.R. Jayewardene, while he was Minister of Finance, was represented at the UNGA 


\section{5th International Conference on New Findings On HUMANITIES AND SOCIAL SCIENCES}

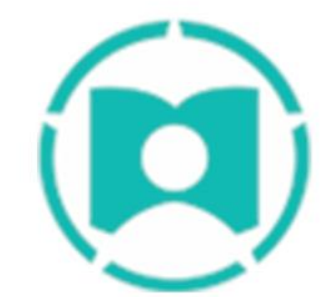

\section{0-22 NOVEMBER, 2020 PARIS, FRANCE}

in 1951. He announced the code of peaceful conduct to global affairs setting forth the values of Buddhism. In 1971, Prime Minister Sirimavo Bandaranaike made another vital statement to the UNGA about the "peace zone" in the Indian Ocean. These two profound speeches captured the attention of the world and underscored Sri Lanka's strong national values in promoting peace and security. The diplomacy of peace practiced today has evolved into a new form during the wartime in Sri Lanka. Peace diplomacy, for example, was not just about how peace is promoted outside, but also about how peace is negotiated inside with the support of outside states.

After 1983, Sri Lanka had to cooperate and distance itself from states in time and time to win and sustain numerous expectations. The Ministry of Foreign Affairs (MoFA) as a State delegate becomes responsible for official foreign representativity generally known as Track I diplomacy. The coordination of the peace strategy for the resolution of the civil war was promoted and negotiated internationally by MoFA with the presence of leaders and representatives. Former (last) Minister of Foreign Affairs Lakshman Kadirgamar, who was a respected visionary leader for a focused FP, was in favour of a peaceful resolution. He was a great supporter of democracy. For instance, in many high-profile speeches, he clearly expressed Sri Lanka's national interest in strengthening security and stability. Minister Kadirgamar has removed the unequivocal view of peace through dedicated diplomatic efforts. The diplomatic turnover that occurred during the peace process from 2002 to 2006.

Sri Lanka seemed to be interested in building confidence and other types of cooperation, i.e., protecting domestic security and economic assistance. In that period, peace diplomacy took a dualistic approach. First, there is peace by negotiation and peace by military means. The third was the blend of the two. These approaches evolved in accordance with the dynamics of war. In short, among the few known countries that were interested in negotiations - the US, India, Norway, Japan and organisations like the UN and the EU admired Sri Lanka's responsibility for peace. Few other bilateral partner states, such as China, Russia, Pakistan and Israel, have championed commercial war objectives by safeguarding bilateral objectives.

The orientation of the obvious peace diplomacy since 2009 can be easily identified as the most complex and thoughtful period of the Sri Lankan CP. The PF's path is not the same as before - and expectations for peace are skyrocketing. Sri Lanka was interrogated inside and out to seek peace through peaceful means - no option criteria were added to reclaim lost opportunities. Leadership and policies had to think of the "new diplomacy of peace" to co-operate with regional geopolitical strategies and changing global interests. Some of the added concerns of the financial planner are, for example: comprehensive security including economic and geopolitical advancement, therefore expanding the scope of peace diplomacy and its continuity.

\section{Small State ' $n$ ' Small State: Norway's involvement in peace.}

The bilateral relationship between Norway and Sri Lanka has evolved since 1952 in the areas of development, humanitarian aid, education and various other forms of aid and assistance. There has been a continuation of relations between the two countries. The two states preferred to be referred to as small states, implying that less paved interest in power and leverage at the international level. Certain requests bilaterally may therefore be compromised. The Norwegian case of peace restoration and consolidation since 2002, as well as the signature of the Ceasefire Agreement (TFA) have become an interesting case 


\section{5th International Conference on New Findings On HUMANITIES AND SOCIAL SCIENCES}

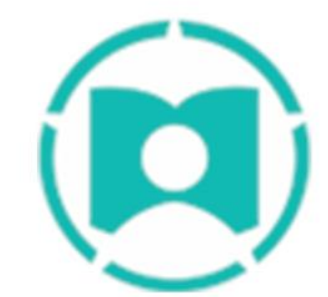

\section{0-22 NOVEMBER, 2020 PARIS, FRANCE}

of Sri Lanka's peace diplomacy reflecting the conscience of the actors. The history of the Oslo Accord, famous worldwide for having negotiated peace in the Israeli-Palestinian conflict, had directed Norway towards the restoration of international peace. While Norway's pursuit of prestige was a national concern in its foreign policy, it was interested in Sri Lanka's call for peace. Sri Lanka's reasoning was plentiful: these are rational and cognitive drivers of Norway-Sri Lanka relations. They are perhaps a little less bound up for a firm analysis but a timely provocation to understand Sri Lanka's FP leadership with peaceful nations.

In addition, Sri Lanka's favour for non-aligned character prompted the choice of Norway as an intermediary for peace. He chose bilateral affairs in the belief that "peace is supported by a peaceful state" - seeing Norway as initially uncontroversial for domestic affairs. Another example is that Norway conducted neutral peace-building operations in the northern and eastern provinces of the island during the 1995-2000 period, when war was looming. In addition, an argument can be made about the desired involvement of a well-known or selected personality as a possible international facilitator.

FP analysts have many reflections on people's choices in interfering with States' external affairs. People's choices are difficult to calculate or seen as specific targets (Farkas, 1996). Going back to Sri Lanka, the three officials involved in the peace dialogue between Norway and Sri Lanka were President Chandrika Bandaranaike Kumaratunga, Norwegian Foreign Minister Knut Vollebaek and LTTE Political Adviser Anton Balasingham Peaceful preferences should first be promoted diplomatically by the two countries. The positions of aid and protection of the Norwegians and their neutral commitment were proclaimed in order to protect not only the territorial integrity of Sri Lanka but also that of India. Later, these diplomatic reasons were motivated by the presence of the Peace Envoy - Erik Solheim saying in the personal interview that "Norway was the only party on which GoSL and the LTTE could agree" (Interview, 25.01.2019). As Hans Brattskar said in an interview with the writer, "We were the privileged international party - we have neither a colonial history nor a security interest in South Asia" (Interview, 24.07.2007). Relations between the two States for peace and development, peace restoration and negotiations have played a positive role in the peace diplomacy of Sri Lanka. Through the regular diplomatic briefing in India on the situation of the peace process, Sri Lanka has managed to maintain a peaceful relationship with its powerful neighbour. So it was facilitated by Norway as well.

The rhetoric changes when domestic policy runs counter to the positive direction of fresh (bilateral) peace diplomacy when it is accused of being - a needless implication, politically biased domestic affairs after some rounds of peace talks. This idea has spread throughout political and public discourse. In the same field, but with the progressive explosion of political uncertainty in the country, Norway has been criticised by the same causes that have expanded peace diplomacy. During the 2005 election campaign, the population voted to abolish the CFA and send Norwegians. Clearly, internal policy distorts diplomacy in response to the timely evolution of desires and context. Ironically, neither diplomatic nor formal conferences/dialogues have sufficiently relieved diplomatic tension to stop the peace process. The diplomatic repercussions on the welfare of peace diplomacy appeared to be influenced by clashes between political figures, conflicts of political consensus and misdirected diplomacy. Sri Lanka is committed to protecting and safeguarding its peaceable relations with Norway. 


\section{5th International Conference on New Findings On HUMANITIES AND SOCIAL SCIENCES}

\section{(a) \\ 20-22 NOVEMBER, 2020 \\ PARIS, FRANCE}

\section{United Nations Sri Lanka for a consolidated peace agreement.}

United Nations delegations are represented and (or) hosted for diplomatic and international cooperation. Those delegations do a lot of work on conflict prevention and peacekeeping. It was there that Sri Lanka had to carefully manage its peace diplomacy under the auspices of the IMF. Unfortunately, it is being used and misunderstood. Sri Lanka's relations with the United Nations since the end of the war seem to make greater use of international leverage than Sri Lanka is forced to quickly re-establish peace after the war. Diplomatic and political debates about interference rather than UN assistance seemed alarming regarding the ongoing peacebuilding. With that Sri Lanka was forced to safeguard its international reputation as a problem-free state. Moreover, since 1952, the United Nations has allowed an abundance of resources and aid for Sri Lanka.

Sri Lanka's competence in peace diplomacy needs more scrutiny. Sri Lanka's GDP growth rate was less than 6 per cent between 2009 and 2018. The World Bank asserts that "Sri Lanka is underperforming (World Bank, 2017). Although Sri Lanka has risen to a higher level in the Global Peace Index, lasting peace is not yet realized. Sri Lanka's peace diplomacy with favorable themes such as "development at the end of the war" and "reconciliation" therefore requires full instrumentalization that captures a holistic approach and tools for implementation, since diplomacy of peace is a multiple approach. Failure to do so can create problems internationally. For example, Sri Lanka raised concerns about improving UNSCR 30/1 at the 40th United Nations Human Rights Council in March 2019. These opportunities are merely a reflection of diplomatic fatigue or diplomatic failures. Simply put, Sri Lanka could take strategic communication standards into account in diplomacy - "when to speak - what to speak - and how to speak" confidence and accountability strategy in the international delegation process.

\section{Foreign Investment Policy}

The concomitant liberalization of trade and foreign investment regimes was a hallmark of Sri Lanka's liberalization reforms. The most significant facet of the new FDI policy was setting up the Greater Colombo Economic Commission (GCEC) in 1978 with wider-ranging ability to set up and operate FTZs.14 The investment promotion policy package offered to FTZ investors was comparable to, or more attractive than, incentive packages of FTZs in most other states. It included (1) permitting complete foreign ownership of investment projects; (2) a tax holiday for up to 10 years with a complete tax exemption for remuneration of foreign personnel employed, royalties, and dividends to shareholders during that period; (3) duty exemption for the import of inputs, and assistance with customs clearances; And (4) industrial services at subsidized rates and limitless admission to foreign-currency credit.

Article 157 of the 1978 Constitution of Sri Lanka provided for a guarantee against the nationalisation of foreign assets without compensation. After the nationalization of foreignowned oil and gas sales points in 1962-64, Sri Lanka became the first country against which the United States (U.S.) the government invoked the Hickenlooper amendment requiring the suspension of U.S. aid to countries that expropriated U.S. goods without (Olson 1977). The constitutional guarantee was therefore vital in re-establishing investor confidence. Under FDI policy, measures have also been taken to conclude investment protection and double taxation agreements with major investing countries. Until 1990, there was no significant change in domestic FDI policy. Such projects were required to go through the regular Foreign Investment 


\section{5th International Conference on New Findings On HUMANITIES AND SOCIAL SCIENCES}

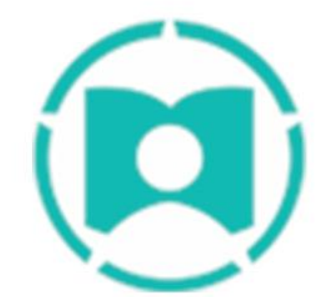

\section{0-22 NOVEMBER, 2020 PARIS, FRANCE}

Advisory Committee approval process, and majority local ownership continued to be the general rule for approving such projects. In 1990, the activities of the Foreign Investment Advisory Committee and GCEC were consolidated as part of a new EC to facilitate and speed up the approval of investments as part of a unified investment-oriented policy the import and export sectors. As part of this institutional reform, restrictions on the ownership structures of joint-venture projects outside FTZs were abolished, export-oriented foreign ventures in all parts of the country were given free-trade status (in addition to the area demarcated by the original GCEC Act), and a new system of automatic approval of projects was introduced in 1990 in place of the case-by-case approval procedure.

In November 1991, BOI was extended to include local investors who establish new exportoriented projects outside the FTA. This proviso, which was initially applicable only to investors who were trained to carry out their projects prior to 30 September 1991, was extended in February 1993 to local investors starting new export ventures as well as existing companies that put up production facilities outside the Western Province. This has become a permanent characteristic of the BOI approval procedure.

However, the evolution of the past decade has begun to send contradictory signals to foreign investors. In 2008 the parliament passed the Strategic Development Projects Act, empowering the minister in charge of the BOI to grant freedoms to "strategic development projects" from all taxes for a period of up to 25 years. In the Act, a strategic development project means "a project which is in the national interest and likely to bring economic and social benefits to the country and which is also likely to change the landscape of the country, primarily through provision of goods and services which will be of benefit to the public, substantial inflow of foreign exchange, substantial employment, and technology transfer" (GSL 2008). This definition leaves a large heap of room for the minister's discretion in the investment approval process, so undermining the BOI's role.

\section{Global economic environment and postconflict developments.}

When the war ended in 2009, the external environment had shifted unfavourably and the scope of "independent" government action had shrunk considerably. The worldwide economy was staggering from the shock of the worldwide financial crisis and the subsequent recession. Sri Lanka, as a net food and energy importer had already been severely hit by the global food price surge of 2007-08 and the high oil prices and growth had slowed in 2008. GDP growth slumped further in 2009 , falling below $4 \%$, though government spending had surged immediately after the close of the fight due to election spending and the demands for urgent reconstruction expenditures. The already large fiscal deficit ballooned from $7.7 \%$ of GDP in 2008 to $9.9 \%$ of GDP in 2009 - breaching the agreement made with the IMF in February 2009 to cut its fiscal shortfall to $7 \%$ of GDP.

Despite this somewhat hesitant beginning of the post-war economic recovery, Sri Lanka appeared to be on the verge of enjoying its peace dividend by 2010 . The external sector (foreign 


\section{5th International Conference on New Findings On HUMANITIES AND SOCIAL SCIENCES}

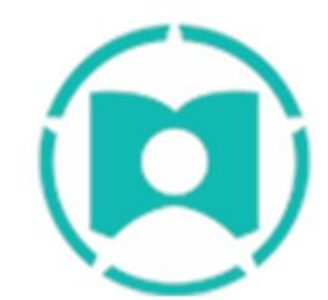

\section{0-22 NOVEMBER, 2020 PARIS, FRANCE}

exchange reserves, export earnings) benefited from improved world economic conditions, domestic agricultural output recovered due to weather conditions, tourism recorded an impressive recovery, remittances from overseas Sri Lankan workers increased, and unemployment declined, GDP grew to 8 per cent, and inflation remained relatively low. The good growth performance continued through 2011, despite a sharp weather-related decline in agricultural production. The Sri Lankan equity market boomed. The government appeared to have succeeded not just in winning the military battle but also to have chanced on a strategy for sustained economic development.

As can be viewed in Table 3, the main drivers of this GDP growth were the non-tradables industries (construction, shipping, service programs, trade and other inspection and repairs), reflecting the significant function of the major public sector building and infrastructure development projects. These sectors accounted for over two-thirds of the total growth in real GDP between 2005 and 2011. Manufacturing grew only at a small pace, resulting in a diminution in its share in GDP from $18.5 \%$ during $2000-04$ to $17 \%$ by 2011 . Within manufacturing, the largest contributor to growth was the food, beverages and tobacco product sector where the output is predominantly domestic market oriented; Sectors such as textile and garment, rubber and plastic products, and non-metallic mineral products where export production is concentrated, recorded much slower development.

A large scale reconstruction effort with public sector participation was clearly necessary after a quarter century of destruction, neglect and decay of essential physical infrastructure. While such projects can give lift to some real exchange rate appreciation and Dutch Disease pressures, such effects are temporary; construction and rehabilitation of infrastructure, strengthen the productive base of the economic system and enables expanded production of both tradables and non tradables, thereby delivers growth benefits over time. However, many government infrastructure projects, such as a modern port and other facilities (being built with Chinese assistance), are located in the Southern regions of Sri Lanka - the heartland of the electoral support base of the Rajapakse family. The prioritization and economic efficiency of these 'flagship projects' are questionable, and they share many similarities with some parts of the public investment program of the UNP government of 1977.

Even where they are largely financed by foreign funds, these projects mobilise significant domestic resources for matching funding and contribute to the budget deficit. Agreeing to the IMF (2010), in 2009, the failure to see the deficit target was due to government spending on 'faster than programmed, lumpy disbursements for a pair of large foreign financed infrastructure projects and for their counterpart funds' (p. 4). They also open up avenues for lucrative contracts and rent extraction by those who hold the levers of state force

The policy reforms initiated in 1977 and sustained over the following three decades produced far-reaching changes in the construction and performance of the Sri Lankan economy, though the land suffered from political turbulence and civil war for much of the menses. But the 


\section{5th International Conference on New Findings On HUMANITIES AND SOCIAL SCIENCES}

\section{(10) \\ 20-22 NOVEMBER, 2020 PARIS, FRANCE}

conflicts prevented the economic system from seizing the broad benefits of reintegrating with the worldwide economy: political instability led to policy instability, massive war financing generated macroeconomic instability, and heightened risk perceptions dampened investor confidence.

In highlighting the importance of economic policies, we do not mean to underestimate the need for a political process that addresses the legitimate and deep seated grievances of the minority Tamil population to ensure a sustainable peace that is indispensable for economic growth. The continued incarceration of thousands, the denial of long standing demands for regional autonomy and withdrawal of concessions that had been previously granted, the rejection of any serious attempt to examine allegations of war crimes, and the strident assertion of the Sinhala Buddhist pre-eminence in Sri Lanka have all contributed to a deepening sense among the minority Tamils that they will continue to be treated as second class citizens despite the rhetoric of reconciliation and equality of treatment. There are already signs of popular dissatisfaction with the mounting cost of living, perceived widening of inequalities, the economic and political prerogatives of the political elite. 30 But, as Sri Lanka's past history has shown, political stability and social public security will be the first victims of economic stagnation or crisis; they can be staved off only if the current statement of both political practice and economic policy are changed sharply, decisively and urgently.

\section{Conclusion}

The main objective of this research are the post-war context in which Sri Lanka's foreign policy and its associated non-aligned policy can identify positive and negative challenges in Sri Lanka from 2009 to 2019. In the context of war the non- aligned policy of bilateral relations with China and India is one of friendship and peace. Sri Lanka's multilateral international foreign policy stands out in peace diplomacy. According to the research, human rights, maritime security strategies and geopolitical challenges can be identified as the main positive and negative challenges of Sri Lanka's foreign policy in the post war period. And other foreign policy problems are in bilateral and multilateral foreign policy can also accountability, the peace process, anti-terrorist laws for disarmament, and the propensity for human rights.

\section{Reference}

Allen, K., Phillip S. and John C. (2017) Chinese Military Diplomacy, 2003-2016: Trends and Implications, Washington,nD. C: National Defense University Press.

Asirwatham, G. (2017) Sri Lanka's Foreign Policy (Guest Lecture), 08th November, University of Colombo, Sri Lanka. 


\section{5th International Conference on New Findings ON HUMANITIES AND SOCIAL SCIENCES}

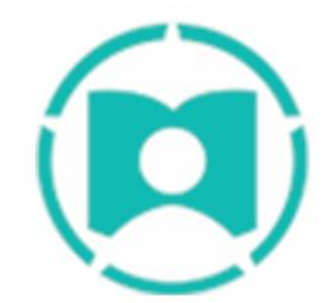

\section{0-22 NOVEMBER, 2020 PARIS, FRANCE}

Ayres, A. and Anderson, A. (2015) Economics of Influence: China and India in South Asia, Council on Foreign Relations. [Online] Available from: https://www.cfr.org/expert-brief/ economics-influence-china-and-india-south-asia [Accessed: 27th February 2017].

Beckley, M. (Winter 2011/12) China's Century? Why America's edge will endure, International Security, 36(3), pp: 41-78. DOI: https://doi.org/10.1162/ISEC_a_00066

Brewster, D. (2015) Sri Lanka tilts back from China, East Asia Forum [Online] Available from: http://www.eastasiaforum. org/2015/09/17/sri-lankas-tilts-back-from-china/ [Accessed: 24th April 2016].

Cheng, Y. S. (2016) Xi Jinping's 'New Model of Major Power Relationships' for SinoAmerican Relations, Journal of Comparative Asian Development, 15(2), pp: 226-254. DOI: https://doi.org/10.1080/15339114.2016.1203342

China Power (2017) How are Global Views on China Trending?, China Power - CSIS [Online] Available from: https://chinapower.csis.org/global-views/ [Accessed: $11^{\text {th }}$ January 2018]

Colombage, D. (2014) Sri Lanka's surging cash reliance on China, Al-Jazeera [Online] Available from: https://www. aljazeera.com/indepth/features/2014/08/sri-lankaeconomyreliance- china-infrastructure-20148256345589851.html [Accessed: 23rd July 2016].

Colombo Telegraph (2014) A Record Increase in Sri Lanka's Defence Expenses For 2015, Colombo Telegraph [Online] Available from: https://www.colombotelegraph.com/index. php/a-record-increase-in-sri-lankas-defence-expensesfor- 2015/ [Accessed: 8th September 2017].

Cooke, G. (2017) Chinese Perspectives of China-Sri Lanka relations: Priorities and Trends, In George I. H. Cooke (Ed) Contemporary China-Sri Lanka Relations, pp: 18-26, Borella, Sri Lanka: BCIS Press.

De Silva, S. (August 2017) Regional hegemony and small state survival: re-examining Ceylon's Foreign Policy under Premier D. S. Senanayake, Paper presented at the International Research Conference. General Sir John Kotelawala Defense University Sri Lanka, Rathmalana, Sri Lanka: General Sir John Kotelawala Defense University.

De Silva, S. (October 2017) A strategic foreign policy nexus: The case of Ceylon and the United Kingdom in the backdrop of India's rise, Paper presented at the Bandaranaike Center for International Studies Emerging Scholars Symposium, Borella, Sri Lanka: Bandaranaike Center for International Studies.

De Silva, S. (2018) Will Sri Lanka manage to perform the balancing act between China and India?, South Asia - London School of Economics [Online] Available from: http://blogs.lse. ac.uk/southasia/2018/01/19/will-sri-lanka-manage-to-performthe- balancing-act-betweenchina-and-India/ [Accessed: $25^{\text {th }}$ June 2018].

De Silva, S. (2015) Balancing, Bandwagoning or Hedging? Independent Ceylon's Reaction to Regional Hegemony, South Asian Survey, 22(2), pp: 189-209.

DOI: https://doi.org/10.1177/0971523117753929 De Silva, S. (2017) Sri Lanka's foreign policy-Security Architecture, Bandaranaike International Diplomatic Training Institute 


\section{5th International Conference on New Findings On HUMANITIES AND SOCIAL SCIENCES}

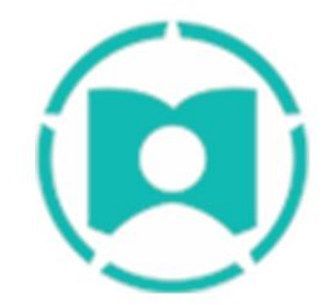

\section{0-22 NOVEMBER, 2020 PARIS, FRANCE}

Blog [Online] Available from: http://bidti. blogspot.com/2017/04/sri-lankas-foreignpolicy-security.html [Accessed: 8th January 2018].

Department of Defense (2017) Annual Report to Congress:Military and Security Developments Involving the People's Republic of China 2017, U. S Department of Defense [Online] Available from: https://dod.defense.gov/Portals/1/Documents/ pubs/2017_China_Military_Power_Report.PDF [Accessed: 25th June 2018].

Ellen, B. (2015) New President in Sri Lanka puts China's Plans in Check, The New York Times [Online] Available from: https:// www.nytimes.com/2015/01/10/world/asia/newpresident-insri- lanka-puts-chinas-plans-in-check.html?rref=collection/ timestopic/Rajapaksa,Mahinda [Accessed: 20th February 2017].

Gamage, R. (2017) Balancing and bandwagoning: explaining shifts in Sri Lankan foreign policy, Journal of the Indian Ocean Region, 13(2), pp: 133-154.

DOI: https://doi.org/10.1080/19480881.2017.1299450 Ge, S. (2017) Remarks, In George I. H. Cooke (Ed) Contemporary China-Sri Lanka Relations, pp: 4-6, Borella, Sri Lanka: BCIS Press.

Gjørv, G. (2012) Security by any other name: negative security, positive security, and a multi-actor security approach, Review of International Studies, 38 (4), pp: 835 - 859.

DOI: https://doi.org/10.1017/S0260210511000751 Goldstein, L. (2015) Meeting China Halfway: How to Defuse the Emerging US-China Rivalry, Washington, D. C.: Georgetown University Press.

Indiatoday.in (2015) India's spy agency RAW behind my polldefeat, says former Sri Lankan president Mahinda Rajapaksa, India Today [Online] Available from: https://www.indiatoday. In/world/story/sri-lanka-president-mahinda-rajapaksablamesindia-raw-for-his's-election-defeat-244216-2015-03-13 [Accessed: 25th June 2016].

Jayawardena, A. (2017) Sri Lankan Perspectives of China-Sri Lanka relations: Challenges and Prospects, In George I. H. Cooke (Ed) Contemporary China-Sri Lanka Relations, pp: 13-17, Borella, Sri Lanka: BCIS Press.

Jian, G. and Xiaoqin, D. (2015) The New Silk Road as an Emerging Model of Regional and International Economic Cooperation-A Brief Review of the International Symposium on "The New Silk Road and China-Africa Economic Relations", International Critical Thought, 5(4), pp: 529-532.

DOI: https://doi.org/10.1080/21598282.2015.1102156 Kahandawaarachchi, T. (2017) Why did Sri Lanka seek Chinese investments in ports?, Daily FT [Online] Available from: http:// www.ft.lk/article/634174/Why-did-Sri-Lanka-seek-Chineseinvestments- in-ports [Accessed: 25th June 2018].

Karunanayake, R. (2017) Sri Lanka to pursue "friendship with all, enmity with none", Colombo Gazette [Online] Available from: http://colombogazette.com/2017/06/02/srilanka-topursue- friendship-with-all-enmity-with-none/ [Accessed: 25th June 2018].

Keohane, R. and Nye J. (2012) Power and Interdependence, $4^{\text {th }}$ Ed, New York: Longman. Kissinger, H. (2015) World Order, New York: Penguin Publishers.

Lone, M. (2017) The new great game in south Asia: theorising the geopolitical outfoxing of India, International Journal of Scientific and Research Publications, 7(5), pp: 127-144. 


\section{5th International Conference on New Findings On HUMANITIES AND SOCIAL SCIENCES}

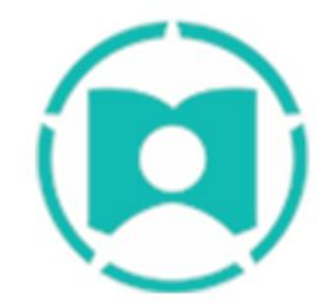

\section{0-22 NOVEMBER, 2020 PARIS, FRANCE}

Lukonin, S. (2017) Redefining Russia's Pivot and China's Peripheral Diplomacy, In Lora Saalman (Ed.) China-Russia

De Silva, Shakthi. (2016). Friendship with All, Enmity with none: An assessment of Sri Lanka's foreign policy in the Times of D.S Senanayake and Maithripala Sirisena. Dbsjeyaraj.com. Retrieved from: http://dbsjeyaraj.com/dbsj/archives/47643 .

De Silva, Shakthi. (2017b). Regional hegemony and small state survival: Re-examining Ceylon's foreign policy under premier D.S Senanayake. International Research Conference. Rathmalana: General Sir John Kotelawala Defense University. 2017.

Gamage, Rajni Nayanthara. (2017). Balancing and bandwagoning: Explaining shifts in Sri Lankan foreign policy, Journal of the Indian Ocean Region, 13 (2), 133-154.

Gjørv, Gunhild Hoogensen. (2012). Security by any other name: Negative security, positive security, and a multiactor security approach. Review of International Studies.

Karunanayake, Ravi. (2017a). Sri Lanka to pursue "friendship with all, enmity with none".Colombo Gazette. Retrieved from: http://colombogazette.com/2017/06/02/srilankato-pursue-friendship-with-all-enmity-with-none/

Karunanayake, Ravi. (2017b). Time to move towards commercial diplomacy in a globalized world.Sunday Observer.Retrieved from: http://www.sundayobserver.lk/ 2017/05/28/features/time-move-towards-commercial-diplomacy-globalized-world

Keohane, Robert O., \& Joseph S. Nye. (2012). Power and Interdependence. 4th Ed. New York: Longman.

Ockersz, Lynn. (2017). Current foreign policy dilemmas of small states: The case of SL.The Island.Retrieved from: http://www.island.lk/index.php?page cat=articledetails\& page $=$ article details\&code_title $=165255$

Panditaratne, Dinusha. (2017). Re-Energising the SAARC Process. Retrieved from: http://www.lki.lk/events/lkis-dinusha-panditaratne-speaks-re-energising-saarc-process/ Samaraweera, Mangala. (2017). Sri Lanka's peace and reconciliation process. News.lk. Retrieved from: https://www.news.lk/fetures/item/15646-sri-lanka-s-peaceandreconciliation- Process

Senadhira, Sugeeswara. (2017). New trio to handle middle-path foreign policy, friendship with all. Ceylon Today. Retrieved from: http://www.ceylontoday.lk/print 20170401CT20170630.php?id=28162

Sirisena, Maithripala. (2016). Collective endorsement of middle path foreign policy. Presidential Secretariat Sri Lanka. Retrieved from: http://www.presidentsoffice.gov.lk/ $? \mathrm{p}=3566$

Uyangoda, Jayadeva. (2016). Taking Sri Lankan foreign policy to the post-confrontational phase. The Wire. Retrieved from: https://thewire.in/46921/taking-sri-lankanforeignpolicy- to-the-post-confrontational-phase/

Hirschman, Albert O. 1964 Stability of Neutralism: A Geometrical Note. American Economic Review 54: 94-100. 


\section{5th International Conference on New Findings ON HUMANITIES AND SOCIAL SCIENCES}

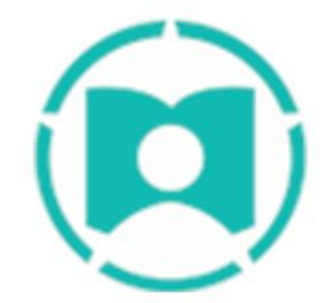

\section{0-22 NOVEMBER, 2020 PARIS, FRANCE}

Johnstone, William C. 1963 Burma's Foreign Policy: A Study in Neutralism. Cambridge, Mass.: Harvard Univ. Press.

Kahin, George M. 1956 The Asian-African Conference: Bandung, Indonesia, April 1955. Ithaca, N.Y.: Cornell Univ. Press.

Lyon, Peter H. 1963 Neutralism. Leicester Univ. Press.

Martin, Laurence W. (editor) 1962 Neutralism and Nonalignment: The New States in World Affairs. New York: Praeger.

Morgenthau, Hans J. 1962 Politics in the Twentieth Century. Volume 3: The Restoration of American Politics. Univ. of Chicago Press. $\rightarrow$ See especially pages 334-341, "Neutralism."

Nehru, Jawaharlal 1950 Independence and After: A Collection of Speeches, 19461949. New York: Day. $\rightarrow$ See especially pages 229-244, "Emergence of India in World Affairs," a speech delivered by Nehru at the Constituent Assembly, New Delhi, March 8, 1949.

Neutrality: Its History, Economics and Law. 4 vols. 1935-1936 New York: Columbia Univ. Press. $\rightarrow$ Written by Philip C. Jessup, Francis Peak, Walter A. Phillips, Arthur H. Reede, and Edgar W. Turlington. 